\title{
ESTUDOS SOBRE A ACULTURAÇÃO DOS GRUPOS INDÍGENAS DO BRASIL *
}

\author{
Eduardo Galvão \\ (Museu Paraense Emílio Goeldi)
}

No congresso de americanistas reunido em Nova Iorque no ano de 1949 , sob o tema aculturação foram apresentadas apenas duas comunicações com referência ao Brasil. Uma, de Wagley, sôbre a cultura do caboclo da Amazônia, e outra, de Willems, sôbre o habitante rural da região sul do país. O ameríndio é citado nesses estudos apenas como elemento que històricamente contribuiu para a atual configuração das respectivas culturas regionais.

E' significativo o fato de essas duas comunicações, apresentadas no Congresso de maior interêsse de estudos americanistas, se referirem à aculturação de populações rurais brasileiras. Sem refletir o que um julgamento mais apressado poderia qualificar de abandono do estudo da aculturação de grupos indígenas, exprimem uma fase de ampliação dos objetivos de estudos antropológicos no Brasil. O índio deixou de ser o foco exclusivo de interêsse e o que se procura é o conhecimento histórico e funcional da transmissão de traços culturais do indígena aos demais contingentes de nossa população - em outros têrmos, a resultante do fenômeno de "aculturação" que resultou do contacto entre índios, europeus e africanos. A caracterização da cultura dessas sociedades rurais constitui elemento indispensável para se aferirem com a necessária precisão os fenômenos de mudanças e transição que sofrem os grupos indígenas em suas relações com nossa frente pioneira.

Nos últimos anos tem se multiplicado pesquisas sôbre populações rurais, e na maioria dos casos conduzidas por antropólogos que tradicionalmente se dedicavam à etnologia do índio, mas os estudos sôbre "aculturação" de grupos indígenas também foram intensificados em ritmo e amplitude. Selecionar alguns dêsses estudos para discuti-los aqui, seria tarefa difícil. Repetiríamos na prática a comunicação do professor Baldus, pois nos trabalhos mais recentes, a partir de Nimuendajú e dêsse etnólogo, seguindo com os de Wagley, Schaden, Watson, Oberg, Altenfelder Silva, Ribeiro, Galvão, Murphy e Hohenthal, mesmo quando não trazem, como acontece em sua maioria, definido em título principal ou subtítulo o tema

(*) Trabalho apresentado à 1a. Reunião Brasileira de Antropologia, realizada no Rio de Janeiro em 1953. 
aculturação, constituem, todos êles, análises de culturas indígenas em transição, e em que o principal fator de mudança deriva de uma situação de contacto com populações rurais brasileiras. Êsse contacto pode ser permanente, esporádico ou, em alguns casos, apenas envolvente ou indireto.

Os Timbíra estudados por Nimuendajú, os Tapirapé por Baldus e Wagley, os Boróro e Kaingáng por Baldus, os Terêna e as tribos do nordeste e noroeste de Mato Grosso, por Oberg e Altenfelder Silva, os Kadiwéu e Urubus por Ribeiro, os Kayuá por Watson, os Tenetehára por Wagley e Galvão, os índios xinguanos por Oberg e Galvão, os índios do Nordeste por Hohenthal, os Mundurukú por Murphy, (os trabalhos dêstes dois últimos ainda não publicados) são exemplos de diferentes fases de transição. Para alguns, como os grupos Kayapó, os Nambikuára e os xinguanos, os contactos diretos com o habitante rural são hostis ou esporádicos. Nesses contactos atuam elementos pioneiros isolados, o seringueiro, o garimpeiro ou os agentes do S.P.I., sem capacidade de intervenção maciça e permanente na cultura indígena. Apesar da natureza dêsses contactos, muitos elementos nossos foram adotados pelos indígenas, desde instrumentos de ferro, armas de fogo até doenças. Mais que a preocupação pela difusão dêsses traços, os etnólogos que estudaram êsses grupos focalizaram sua atenção nas mudanças totais promovidas não apenas pela adoção do facão ou do machado de ferro, mas pelo próprio fato de envolvimento da sociedade indígena pelas povoações rurais. A retração dos territórios de agricultura de caça e coleta, a diminuição de população em conseqüência de contágio de doenças, a modificação de status e prestígio social advinda da posse de artigos importados, a desorganização das instituições sociais, são fenômenos que em relação a êsses grupos citados não poderiam ser estudados sob a epígrafe da aculturação, em sua definição rígida, que exige como condição essencial o contacto direto e contínuo entre grupos portadores de culturas diversas.

Grupos indígenas, como os Kayuá, Kadiwéu, Terêna e Tenetehára, já estão envelhecidos no contacto permanente com a nossa sociedade rural, que em alguns casos data de dois ou três séculos. O índio age aí como elemento receptor simplesmente. A transmissão de traços segue uma direção, partindo da cultura do caboclo para a do indígena. Os elementos culturais dêste já não são aproveitados pelo caboclo, o qual em gerações passadas saturou, por assim dizer, a sua capacidade de assimilação de traços do ameríndio. A aplicação do conceito de aculturação estaria metodològicamente correta para o estudo dessas situações. Entretanto, tem sido de modo relativamente frouxo e em algumas das monografias o acento principal recai sôbre problemas de assimilação ou de mudança cultural. Mais que a verificação, o registro do mecanis- 
mo de mudanças ocorridas nessas culturas indígenas, o investigador é chamado a explicar a mudança dessas culturas no sentido de sua assimilação à cultura nacional. Mesmo quando o índio se retrai e reage no sentido de retôrno à condição tribal, valorizando os elementos tradicionais e o seu status de índio, tal como sucede para os Canelas, Xerênte e Apinajé, estudados por Nimuendajú, ou entre os grupos tribais do Nordeste e do Sul que habitam regiões de forte densidade demográfica e que algumas vêzes são definidos como índios aculturados, essa atitude é um mecanismo de assimilação. A única coisa que permite a êsses índios, na competição econômica com o "branco", manter a posse de uma gleba ou de garantir a si próprios um mínimo de assistência é fazer valer sua condição de índio. Dêsse ponto de vista, um dos estudos mais promissores, será o de Hohenthal sôbre os grupos do Nordeste. A maioria dos estudos citados, embora sem desprezar êsses aspectos chamados de aculturação, se orientam mais para a identificação dos padrões tradicionais, menos para as semelhanças entre índios e caboclos.

Dadas as dificuldades que para efeitos de um balanceamento crítico encontraríamos em distinguir os estudos de aculturação sob uma definição rígida dêsse conceito, achamos mais construtivo para a nossa reunião de hoje, discutir o conceito de aculturação em si mesmo.

Mesmo anteriormente à clássica definição do têrmo segundo o Memorando de Redfield, Linton e Herskovits, a aculturação já era um conceito usado para definir as resultantes culturais do contacto entre dois povos. Estudos de difusão foram, como ainda são, estudos de aspectos selecionados de aculturação. Preocupa-se o investigador pelo mapeamento da distribuição de determinados traços, transmitidos de um povo a outro, mesmo quando o contacto dêsses povos não fôsse direto ou permanente, condições pelas quais se veio a distinguir aculturação de difusão. O mais importante, porém, foi dirigir o interêsse da investigação para o mecanismo de mudança cultural em processo. A situação de contacto direto e permanente entre dois ou mais povos, e o que disso resultava, trocas culturais, fornecia ao investigador uma condição de laboratório para o estudo dos processos envolvidos nessas trocas. Justifica-se, por isso, o empenho dos pioneiros nesse campo em caracterizar os fenômenos estudados, de um modo que nos parece hoje demasiado rígido, senão insatisfatório como instrumento de pesquisa.

Aculturação foi definida como o estudo dos fenômenos que resultam quando grupos de indivíduos possuindo culturas diferentes entram em contacto direto e permanente e das conseqüentes mudanças nos padrões culturais dêsses grupos. Distinguiu-se aculturação de mudança cultural, de que é um aspecto, e de assimilação, que pode ser uma fase de. aculturação, e ainda de difusão, que, embora concorrente ao processo de aculturação, necessàriamente não exige o contacto entre povos. Essa con- 
ceituação foi posteriormente criticada pelos próprios autores, especialmente porque deixava de caracterizar a "natureza" do fenômeno e pela dificuldade de estabelecer um critério adequado para definir a situação de contacto. Em casos conhecidos, fenômenos que poderiam ser considerados como de aculturação, resultavam não do contacto maciço e permanente entre duas sociedades, mas da influência de uns poucos indivíduos sôbre uma dessas sociedades. A atuação de missionários, por exemplo.

Outra dificuldade residia em estabelecer os limites entre "aculturação" e mudança cultural, pois em muitos casos o empréstimo e a adoção de um traço cultural são sincrônicos com modificações que derivam de fôrças internas da cultura receptora.

O problema não é de terminologia, mas de atitude teórica diante do fenômeno de mudança cultural, seja ela resultante de fatôres internos, inerentes à própria cultura, seja resultante de contacto entre dois povos, ou de ambas as causas.

Vejamos dois exemplos, o primeiro com referência aos índios Kayapó e os xinguanos. Aquêles são índios hostis, êstes pacíficos, mas cujo contacto com sertanistas data de apenas dez anos. A despeito da ausência de relações permanentes com civilizados, êsses grupos já possuem considerável acervo de artigos de nossa cultura - ferramentas, armas, objetos de adôrno, tomados em ataques a povoados sertanejos ou adquiridos por via de outras tribos.

O empréstimo cultural não se limitou apenas a êsses objetos. Ocorreram outras modificações. Alteraram-se as relações entre aldeias e a própria estrutura social tende a ser influenciada, especialmente no que se refere ao status de chefia. Entre os Kamayurá, reconhecia-se a autoridade e o título de um capitão, patente que the é dada por funcionários do S.P.I., em uma viagem que êsse indivíduo realizou em tempos anteriores à atual penetração do Xingu. Não satisfaria a um etnólogo a catalogação dêsses fenômenos de mudança em categorias de difusão e de aculturação, o fato que realmente interessa é o processo de mudança. A simples presença de civilizados em tôrno de um território indígena, mesmo quando não se estabelecem relações diretas, é um fator condicionante de mudanças na cultura indígena.

O segundo exemplo se refere a índios cujo contacto direto e permanente com civilizados data de dois ou três séculos. Caso "típico" de aculturação, como se pode observar entre os índios Tenetehára, do rio Pindaré, Estado do Maranhão. Mas os objetivos de uma pesquisa etnológica seriam falhos, se limitados neste caso a "fenêmenos do nível aculturativo", segundo o conceito clássico. O fulcro da mudança cultural dos Tenetehára resulta não apenas dos empréstimos, não apenas de ferramentas, introdução de novas espécies de cultivo, e a sua mobilização para 
a coleta de babaçu, como das relações econômicas entre índios e civilizados. Se foi importante a transformação de uma agricultura de subsistência em uma de produção de comércio, a oscilação de preços na praça nacional e estrangeira para o babaçu, principal produto de coleta e via de integração do Tenetehára na economia local, é um dos fatôres condicionantes de assimilação e de mudança cultural dêsses índios.

Diante dêsses problemas, uma abordagem limitada apenas a aspectos que poderiam ser considerados "aculturativos" teria pouco valor. $\mathrm{Na}$ realidade, as culturas indígenas têm sido aproximadas de maneira mais inclusiva. O nosso conhecimento do ameríndio está agora alcançando um nível mínimo de suficiência, e os ensaios de caracterização de áreas regionais sòmente agora vêm de ser iniciados.

Nas monografias sôbre grupos indígenas os capítulos de aculturação ou de mudança cultural sofrem ainda de certa limitação que advém da falta de conhecimento da cultura cabocla ou da frente pioneira que entra em contacto com o índio. As observações, ou a constatação de aculturação são acentuados em tôrno de alguns elementos de cultura material, como ferramentas, roupas, utensílios domésticos e idéias religiosas. Nossa preocupação maior tem sido a de reconstituir a cultura tradicional. O que não está errado, pois essa reconstrução histórica é essencial para se compreender o mecanismo das mudanças que tiveram lugar, mas que de certo modo nos tem tolhido, ou pelo menos, não facilitado a visão de problemas mais dinâmicos. O objetivo da antropologia, afinal de contas, não é apenas descrever as culturas indígenas como se encontram no momento, mas o de tentar alcançar a dinâmica e o funcionamento de transmissão e de mudança cultural. Em outros têrmos, buscamos generalizações sôbre o fenômeno cultural, não apenas a etnografia das tribos do Brasil.

Devemos esquecer um pouco aculturação e pensar mais em assimilação. Em nossa monografia sôbre os índios Tenetehára, nos deixamos empolgar pelo ritmo relativamente acelerado de transição dessa cultura indígena para os padrões brasileiros. Embora o grupo mantenha sua unidade tribal e possa ser distinguido da população cabocla por uma configuração cultural diferente, são evidentes os sinais de desgaste da cultura tradicional e as de substituição de valores tribais por outros, brasileiros, resultantes do impacto de trezentos anos de convívio geralmente pacífico com nossa sociedade rural. Concluímos que não demoraria talvez mais que uma ou duas gerações para que os Tenetehára se transformassem em caboclos. Sòmente a experiência que adquirimos no Serviço de Proteção aos Índios, onde nos familiarizamos com uma variedade de situações de contacto e assimilação de grupos indígenas, nos permitiu uma perspectiva mais correta. E' bem possível que os Tenetehára em certo ponto de sua transição tomem por outra alternativa que 
a de aderir à cultura cabocla, a mesma que escolheram os indígenas do Nordeste e do Sul do país, onde, atingida certa estabilidade de população e de relações com os "brancos", e a consciência da impossibilidade de integração na sociedade rural, exceto em seu degrau mais inferior, o indio resolva permanecer índio, categoria sócio-cultural que the garante condições de sobrevivência e de status social nas comunidades regionais.

Um outro problema é o de modalidades de aculturação. Embora não tenhamos até o presente um trabalho sôbre o assunto, exceto aquele pioneiro de Baldus, que data de 1937, sob o título "A mudança de cultura entre índios do Brasil", constantemente discutimos as prováveis causas de alguns grupos se "aculturarem" com maior facilidade que outros. O cáso padrão se refere aos Timbíra ou aos Karajá, notados por sua aparente resistência à assimilação, e a grupos Tupí, pela receptividade que julgamos possuírem para nossos traços culturais. As explicações dêsse fenômeno têm sido várias. As mais satisfatórias se referem ao que se pode chamar "distância cultural". Nesse sentido, os primeiros (Kayapó e Karajá) participam de culturas de tal modo especializadas ao ambiente e com tais características que as afastam muito daquela dos caboclos, em cujo substratum cultural se identifica muito do Tupí. E' uma hipótese a se verificar, mas que, mesmo comprovada, está a exigir estudo mais detalhado. Os fatôres de resistência e de apêgo a padrões tribais parecem a nós residir mais em causas que dizem respeito à expansão da população sertaneja brasileira. Um fato que tem sido pouco salientado é que êsses grupos mais resistentes ocupam em geral as zonas menos devassadas, mais inóspitas do planalto central, e onde não se registraram tentativas de assimilação do índio e fixação do caboclo, ou aquêle não encontrou um lugar permanente na economia regional. A resistência dêsses grupos é uma condição de sobrevivência. Em outros casos a súbita expansão de população brasileira que se defronta com grupos indígenas pouco numerosos não permite um espaço de tempo necessário a uma acomodação. O índio se retrai ou é empurrado para mais longe. Seu pequeno número o coloca em posição de inferioridade, de minoria étnica, sem outra alternativa que a de perecer. E' o caso, por exemplo, dos índios do Xingu, que, a despeito do grande número de tribos, estão em vias de extinção. A maior delas possui pouco mais de 140 indivíduos. De um período de isolamento vieram a se defrontar há cêrca de dez anos com aviões, máquinas e um tipo de colonização em que seu braço não será reclamado. Sem um lugar nessa economia e sem uma densidade demográfica que possa resistir ao desgaste forçado pelas circunstâncias do contacto, principalmente a diminuição de número pelo contágio de moléstias, tenderão a desaparecer, exceto se fôr desenvolvida uma política indigenista com eficiência bastante para lhes fornecer os meios de acomodação e assimilação. 
Citamos êsse fator, porque nos estudos de aculturação e de mudança cultural está sempre implícita a condição de assimilação à cultura dominante e às perspectivas dessa assimilação. Embora os estudos de aculturação não sejam orientados, na maioria dos casos, com objetivos práticos de traçar prcgramas de antropologia aplicada, é nesses estudos que os administradores encarregados da política indigenista têm procurado ou devem procurar inspiração para seus planos. A êsse respeito é interessante reproduzir o pensamento de Steward: Os estudos de aculturação não são, naturalmente, idênticos aos da antropologia aplicada, mas materiais para o estudo de ambos os campos serão muitas vêzes os mesmos ou ao menos coincidirão; é necessário que um espírito de absoluta objetividade científica presida a ambos. De fato o administrador de qualquer programa estará muito mal servido se a pesquisa relaxar de qualquer modo suas diretrizes científicas ou fôr conduzida sem o fundamento teórico necessário.

As necessidades e os problemas para a pesquisa de situações de "aculturação" ou de mudança cultural para a América Latina, apontadas por Steward podem bem ser transpostas para a nossa condição regional.

Assim, em nosso país, quaisquer estudos de mudança cultural, ou, para usar do têrmo corrente, tomado pràticamente como seu sinônimo, de aculturação, estão a exigir:

a) intensificação dos estudos monográficos sôbre grupos indígenas, orientados ao mesmo tempo para a compreensão da situação cultural em que atualmente se encontram, como para a reconstituição das mudanças que ocorreram, tomando-se como ponto de referência as culturas tribais até onde é possível reconstituir a história dessas tribos;

b) na base dêsses estudos a tentativa de caracterização de áreas culturais em esquemas menos simplificados que os atualmente em voga; áreas culturais tomadas aqui, não apenas no sentido de distribuição geográfica de um conjunto de traços e padrões, mas da relação dêsses traços ao meio ambiente;

c) pesquisa das comunidades regionais em contacto com as tribos indígenas, senão seu estudo intensivo, pelo menos um conhecimento das diretrizes culturais dessas comunidades, que são os fatôres condicionantes da "aculturação" ou mudança cultural do índio. Em outros têrmos, passar de um inventário de traços de cultura para uma análise de interação de configurações culturais;

d) caracterização de áreas regionais incluindo a sociedade rural e as sociedades indígenas, o que alguns talvez chamariam de faixas de aculturação, mas que preferimos designar por etapas, mudança cultural no tempo e no espaço; 
e) e, como corolário, o reconhecimento das diretrizes sócio-culturais dessas áreas regionais que atuam como fatôres condicionantes da "aculturação", ou, como preferimos, da assimilação do índio.

$E^{\prime}$ evidente que a um único investigador a satisfação dêsses requisitos é pràticamente impossível, tornando-se indispensável o trabalho de equipe e a colaboração inter-disciplinar. Do ponto de vista científico justifica-se plenamente o estudo monográfico de qualquer de nossas tribos indígenas, em qualquer estágio de aculturação, tomando-se como ponto exclusivo de interêsse a tribo escolhida para pesquisa. Mas de qualquer maneira, e isso com especial referência às instituições que patrocinam as pesquisas antropológicas, faz-se mister a reunião de especialistas e a coordenação de suas pesquisas em tôrno de problemas de interêsse teórico mais amplo que os de iniciativa individual. Não se trata de dirigir pesquisas etnológicas de modo praticista, mas de coordenar esforços e recursos para a análise de problemas de interêsse teórico generalizado que realmente beneficiem nossa ciência. De outra forma continuaremos a marcar passo nas tentativas pioneiras, brilhantes em sua maicria, mas de resultados ainda aquém das possibilidades de seus realizadores e dos recursos utilizados nessas pesquisas. 